DENIS RENEVEY

I 2 I 5-I 349: texts

The previous chapter suggests that the canons issued under the authority of Pope Innocent III on the occasion of the Fourth Lateran Council of $x_{2} 15$ officially licensed, codified, and reinforced newly emerging trends in the clerical practice of pastoral theology. This foundational moment in the history of the western church had a lasting effect on the way the medieval self was to be shaped. The Lateran documents shaped medieval religious psychology and its attendant literature by encouraging the production of pastoral manuals and manuals of confession to assist priests in the exercise of their new responsibilities in the care of souls (cura animarum). Canon Io of the Fourth Lateran Council acknowledges that bishops may require the support of capable men who, in lieu of the bishop, will preach in his diocese. ${ }^{\mathrm{I}}$ The continuing implementation of this legislation in England produced further constitutions, including influential sets by Bishop Richard Poore (d. I237) of Salisbury in I222, and Bishop Robert Grosseteste (c. II7O-I253) of Lincoln in $\mathrm{x} 239$. These diocesan constitutions were codified for the whole of Canterbury Province (and in effect for the whole of England) in the I28I Lambeth Constitutions of Archbishop John Pecham (d. I292). Through such routes basic catechetical material was circulated for the use of parish priests in the pastoral care of their flock. This material was glossed and the needs of priests supported in newly composed Latin pastoral manuals, such as William of Pagula's (c. I290-I332) Oculus sacerdotis (The Eye of the Priest), written in the $\mathrm{I} 320$ and used, for example, by Richard Rolle. ${ }^{2}$ Religious vernacular textual production between I 2 I 5 and I 349 bears witness to this increased insistence on penitential self-introspection as encouraged by the official church. If it is indeed a hallmark of several of the vernacular theologies written from I21 5 onwards, such a characteristic blends with, and gives new impetus to, the affective tradition which marked twelfth-century monastic spirituality.

Vernacular theologies from the period I2I 5 to I349 typically address the emotional, affective side of the human psyche in order to move it to 
greater desire for the divine. Appealing to human emotions in order to

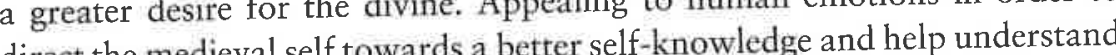
the nature, and experience of, a personal relationship to God, such texts generated a form of 'contemplative feeling' whose growth will be explored in the course of this chapter. ${ }^{3}$

\section{Anchoritic texts}

The most far-reaching vernacular religious texts to emerge in the decade or founcil are a group of highly specialized works so following the lat west Midland area, which promoted this form originating in the West Midland area, which promoted this form of 'contemplative feeling'. Ancrene Wisse initially addressed an audience of three female anchorites. Anchorites lived solitary lives in cells or group of cells near or adjacent to a church. In the latter case, a window would allow the near or adjacent the church seranchorite to peer into the church and atend, from the cell, the church services. Anchorites led a life based on the model of the desert fathers, although their desert was understood metaphorically to signify their isolation from the world and their attempt to commit themselves to a life of reading, the world and the practical and spiritual aspects of the anchoritic life are prayer, and devoin. a major concern of Ancrene Wisse. Structurally divided into eight books, or 'destinctiuns', Ancrene Wisse reflects developments in contemporary intellectual and academic thought in its layout and careful division of its material. The text was composed after $12 x_{5}$, possibly by a Dominican friar engaged The text ws com council's new pastoral priorities, in the implementation of the Lateran Council's new pas notably the need for all Christians to confess annually. The first and the last 'destinctiuns' address external aspects of the life of an anchorite, and form the outer rule, while 'destinctiuns' two to seven focus on aspects of the fin 4 Part One provides for the three sisters inner life and forn the inner rule. Part One provides for the three sisters who make the primary audience of Ancrene Wisse an adjustable devotional template and useful information about their suggested daily devotional routines. The last book, itself subdivided into seven branches, deals with the res. anchorhold as a religious household, with such diverse regulation of the anchor concerns as the reception of visitors, handling of material goods and an mals, circulation of knowledge from the anchorhold to the outside world, and the general behaviour of the anchoresses, their spiritual guide and confessor, and the anchoresses' maidservants. The central part of the inner rule deals with the technology of confession, laid out in a most detailed fashion, and also apparently intended for the use of a wider audience. Indeed Parts Four to Six ('Temptations', 'Confessions', and 'Penance') are all potentially universal in their address and share similar concerns with other pastoral theologies written following the Fourth Lateran Council:
Al thet ich habbe i-seid of flesches pinsunge nis nawt for ow, mine leove sustren - the other-hwile tholieth mare then ich walde - ah is for sum thet schal rede this inoh-reathe, the grapeth hire to softe.

All that I have said of the mortification of the flesh is not meant for you, my dear sisters, who sometimes suffer more than I would like; but it is for anyone who handles herself too gently who reads this willingly enough. ${ }^{5}$

In the Corpus manuscript, which may have been revised by the author himself, reference is made to a much larger community of anchoresses living throughout the whole of England (Ancrene Wisse, p. 270; Anchoritic Spirituality, p. I4x). The author therefore seems to assume a multiple anchoritic audience. However, considering the significant confessional material that makes the core of the treatise, it may be that, from the onset, Ancrene Wisse was not exclusively designed for an anchoritic audience. For instance, while the following passage has literal applicability to real anchoresses, there is also always the possibility of a more metaphorical meaning, addressing a non-anchoritic audience who are equally interested in the exploration of the interior life:

Ant nes he him-seolf reclus i Maries wombe? Theos twa thing limpeth to ancre: nearowthe ant bitternesse, for wombe is nearow wununge ther ure Laverd wes reclus, ant tis word "Marie," as ich ofte habbe i-seid, spealeth "bitternesse." Yef ye then in Yef ye thenne inearow stude tholieth bitternesse, ye beoth his feolahes, reclus as he wes i Marie wombe. Beo ye i-bunden in-with fowr large wahes? - ant he in a nearow cader, $\mathrm{i}$-neilet o rode, i stanene thruh bicluset hete-feste! Marie wombe ant this thruh weren his ancre-huses.

And was he not himself a recluse in Mary's womb? These two things belong to the anchoress: narrowness and bitterness. For the womb is a narrow dwelling, where our Lord was a recluse; and this word "Mary," as I have often said, means "bitterness." If you then suffer bitterness in a narrow place, you are his fellows, recluse as he was in Mary's womb. Are you imprisoned within four wide walls? - and he in a narrow cradle, nailed on the cross, enclosed tight in a stone tomb. Mary's womb and this tomb were his anchorhouses.

(Ancrene Wisse, p. 370, Anchoritic Spirituality, p. I86)

Such images of confinement and enclosure are semantically loaded: considered more loosely, they could be used more generally by an audience wanting to experience the spiritual pregnancy of contemplation. Reference to the humanity of Jesus invites comparison with one's own life: the immediate and implied parallel is with the anchoritic mode of life, but it does not exclude other possible comparisons. The anchorhold in Ancrene Wisse is defined as an extension of the body, a necessary container of the soul, as the author reminds us when talking about the anchoress living, like Christ, in thos 
confined spaces: 'thet schal beon hwen the gast went ut on ende withuten confine the licome. Thet other is the bruche ant wem of his twa huses: thet an is the licome. Thet other is the
utter hus, thet is as the uttre wah abute the castel.' ('That will be when the spirit goes out in the end, without break or blemish, from its two houses. One of them is the body, the other is the outer house, which is like the outer wall around a castle') (Ancrene Wisse, p. 370; Anchoritic Spirituality, p. 187$)$.

Ancrene Wisse's organized structure and general rational approach to the anchoritic/contemplative life aims to lead its readership to the pinnacle of the Christian life, achieved only after contemplating or even experiencing the Christian life, achieved only after conten rigorous ascesis (self-discipline, usually achieved by rigorous bodily discipline). While highly specialized, Ancrene Wisse is nevertheless influenced by contemporary pastoral theology in whose diffusion the friars, and espebially cially the Domicans, the text moves beyond its pervasive anchoritic asceticism, the spirituaty of the text moves towards that advocated by the twelfth-century Cistercians such as Bernard of Clairvaux on the Continent and Aelred of Rievaulx in England. Part Seven of Ancrene Wisse suggests, for example, a form of spiritual love that is Toints a mysical moment which one reads as the culminalover/knight. It points to a mystical moment which one reads as the culmination that one attains if the doctrine expounded in the rest of the treatise has been well digested. Imagery from the world of romance is fused with images been well digest though brief, it alludes to the potential of ecstatic experience and thus depicts contemplative feeling:

'Thi luve,' he seith, '- other hit is for-te yeoven allunge, other hit is to sullen, other hit is to reavin ant to neomen with strengthe. Yef hit is for-te yeoven, hwer maht tu biteon hit betere then up-o me? Nam ich thinge feherest? Nam ich kinge richest? Nam ich hest i-cunnet? Nam ich weolie wisest? Nam ich ich kinge rich? monne hendest? Nam ich thinge freoest? For swa me scih bi lage mon the ne con nawt edhalden, thet he haveth the honden, as mine beoth, i-thurlet. Nam ich alre thinge swotest ant swetest?'

'Your love,' he says, 'is either to be wholly a gift, or it is for sale, or it is to be taken and captured by force. If it is to be a gift, where could you bestow it better than upon me? Am I not the fairest one? Am I not the richest king? Am I not highest born? Am I not the wisest among the rich? Am I not the most courteous of men? Am I not the most generous one? For one says of a generou man who can keep nothing back, that his hands are pierced - as mine are. Am I not of all things the gentlest and sweetest?'

(Ancrene Wisse, pp. 385-6, Anchoritic Spirituality, pp. 193-4)
Ancrene Wisse looks like a multi-purpose text. Its generic complexity (is it a rule, a confessional manual, a pastoral treatise?), its indebtedness to traditional Augustinian monastic practices and its borrowings from thirteenth-century academic discourses (especially its use of distinctio structure) probably contributed to making it a popular, multi-functional religious text. It is also a strong reminder of the cultural diversity of England, with French and Latin taking a significant role in the making of English religious identity. Its comfortable after-life is attested by seventeen extant manuscript versions, in English (nine), French (four), and Latin (four). Further evidence of popularity is attested by the number of borrowings from Ancrene Wisse in devotional and contemplative texts in the fourteenth and fifteenth centuries. The nature of the borrowings and their new contextualization show how the anchoritic model (used metaphorically) became a trademark for exemplary religious life, both for the more laicized and urban devout public and the (male) monastic public of this later period.

'Loke, Lauerd, to me, mi lif, mu luue, mi leofmon, ant milce me, pi meiden,' Seinte Margarete.

'Lord, watch over me, my life, my love, my lover, and have mercy on me, your maiden', Saint Margaret. ${ }^{6}$

As with the metaphorical appropriation of anchoritic culture for a diverse public, vernacular literature extolling the spiritual benefits of virginity also bears a metaphorical dimension which should not be underestimated when considering its functions, and the various linguistic conduits (AngloNorman, English, and Latin) which serve for its circulation. The virginity texts associated with the West Midland dialect and early manuscript circulation of Ancrene Wisse display exemplary female lives as models to be used for the direction of one's own life. Faith and virginity are inextricably linked: the extremes of pain and suffering which female characters are ready to undergo to preserve their virginity stand as the measure of the intensity of their faith.?

In the case of Seinte Margarete, the female heroine is depicted as a passive and suffering virgin, physically enduring a form of imitatio Christi (imitation of the life of Christ, more specifically the Passion events) by having her body tortured through the creative perversity of her male tormentor Olibrius. Tha heroic moment of passive endurance is counterbalanced by a second phase which depicts a warrior-like Margaret governing and annihilating the power of demonic visitations in the form of a dragon or other devilish creatures. Like those of St Katherine of Alexandria and St Juliana of Nicomedia, this saint's life portrays a combative female character whose life calls for affective 
empathy, Even an anchoritic audience would not aspire to a literal imitation f hos dives could strengthen any religiously committed audience in the face of adversity. These saint's lives point to virginity as the spiritual condition most favoured by the deity. A treatise on holy virginity, Hali Meiðhad, travelling with these the deity. A treatise on holy virg in the same dialect, make virginal lives the spiritual condition most favoured by the deity. The spiritual quality-gap between matrimony/motherhood and virginity is unequivocal:

Hwenne schulde Ich al habben irikenet pet springeð bituhe peo pe pus beoð igederet? zef ha ne mei nawt temen, ha is icleopet gealde; hire lauerd luueô hire ant wurdged be leasse, ant heo, as peo pet wurst is prof, biweped hire wirdes, ant cleoped ham wunne ant weole fulle be temed hare teames. Ah nu wurdes, ant cleoped ha hilneð, ant loki we hwuch iwurde hit al pet ha habbe hire wil of streon pet ha wio wunne prof hire iwurðe. I pe streonunge pron is anan hire flesch wio pet fulpe ituket, as hit is ear ischawet; I pe burðerne prof is heuinesse ant heard sar eauer umbe stunde: in his iborenesse, alre stiche strengest, ant dea operhwiles; in his fostrunge forð, moni earm-hwile.

When should I have finished an account of everything that comes between those who are joined in this way? If she cannot have children, she is called barren: her lord loves her and honours her less, and she, as the one who has the worst of it, bewails her fate, and calls those women who do bear children full of happiness and good fortune. But now suppose that it turns out that she has of the wanted in the child that she longs for, and let us see what happiness she all she wanted the filth, as has gets from it. In conceiving it, her flesh is at once defiled with that filth, as has been shown before; in carrying it there is a heaviness and constant discomfort, in giving birth to it, the cruellest of all pains, and sometimes death; in bringing it up, many weary hours. (Medieval English Prose for Women, pp. 28-3I)

The case for the superiority of virginity is here based on the physical conThe case for the matrimony and motherhood. But this gender-based straints of its opposich male readers could also identify.

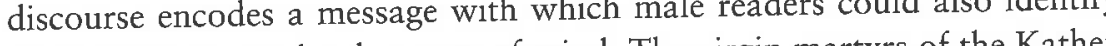
virginity is, on one level, a state of mind. The virgin martyrs of the Kather ine group exemplify the androgynous-feminine type of holy life, which is characterized by penitential asceticism. These stories repeatedly stage a concharactize subjection, which is characterized by trast between male power and fennis those qualities were passive forbearance and obstinate constancy. Because those qualities were typically gendered as feminine in the medieval period, it can be initially shocking to find that the medieval Passion narratives attribute those qualities to the person of Christ. But the feminization of Christ allows for those narratives of female subjection to resonate with Christ's passion. Therefore the lives of the female martyrs potentially read as active re-enactments of the Passion: their performance by a female or male audience allows for a closer and soundly orthodox apprehension of the experience undergone by God in his humanity. The female saint's subjection to barbaric power makes them ungendered heirs to Christ.

The three sisters for whom Ancrene Wisse was written had not experienced monastic enclosure and its way of life before entering their anchoritic cells. Their ability to read in the vernacular, as well as their apparent literacy in liturgical Latin, reflect the degree of competence reached by female lay readers of gentle birth in the thirteenth century. Because the number of postulants for entry into anchoritic cells was always limited, one can assume that many lay people of gentle birth would have had some of the same hermeneutic skills assumed in the anchoresses. These texts would have been suitable for an audience beyond the enclosure of the anchoritic cell: this specialized literature had a decisive impact on the making of religious books for the attention of the laity. Canon I 3 of the Fourth Lateran Council prohibited the foundation of new religious orders and as a consequence some individuals were prevented from joining orders that could have catered for their affective religious needs. The scarcity of new institutional contexts for the practice of affective piety accounts in part for the surge of lay devout activity in the thirteenth century, in parallel to monastic and anchoritic practices. The transmission of spiritual material from the monastery to the anchorhold and beyond into the lay world at large is concurrent with, and dependent on, the use of vernacular languages for their dissemination.

The texts which constitute 'The Wooing Group', for example, resonate with the imagery developed in the Cistercian commentaries of the Song of Songs, while at the same time addressing the reality of anchoritic life. But, they also have an affective quality with which a lay readership would have felt comfortable. That the text called Pe Wohunge of ure Lauerd survives in only one manuscript is counterbalanced in terms of possible popularity and dissemination by the fact that it eventually found its way into two late fourteenth-century bulky devotional anthologies of vernacular spiritual material, the so-called Vernon and Simeon manuscripts, as a compilation called $A$ Talking of the Love of God. ${ }^{8}$ Few other medieval vernacular poems vibrate with the affective intensity of $P e$ Wohunge of ure Lauerd, the central piece of 'The Wooing Group'. The 658-line alliterative prose text abounds in imagery derived from the commentary tradition of the Song of Songs, fin' amor literature, the conventions of chivalric behaviour, and the lexis of 
kinship and exile. The imagined exchange between an I-persona and Christ is so craftily designed that it privileges an emotional performative reading in which the reader engages dialogically with force reaches its climax towards the end of the poem, which describes the Passion of Christ: A water. A nu is mi lefmon dend for to deien. A nu mon ledes him ford to munte caluarie to pe cwalm stowe. A lo he beres his rode up on his bare schuldres and lef pa duntes drepen me pat tai pe dunchen ant prasten pe forðward swiðe toward ti dom... A swete iesu pu oppnes me pin herte for to cnawe witerliche ant in to redden trewe luue lettres; for per i mai openlich seo hu muchel pu me luuedes. Wið wrange schuldi pe min heorte wearnen siðen pat tu bohtes herte for herte.

Ah! What shall I do now? Now my heart can break apart, my eyes all overflow with water. Ah! now is my lover condemned to die! Ah! now they lead him toward Mount Calvary, to the death-place! Ah! see, he bears his cross upon tow bare houlders and, beloved, would that those blows would fall on me his bare shoulders and, beloved, would the ho blews woun with which they strike you and thrust you so violently forward toward you doom... Ah! sweet Jesus, you open your heart to me, so that I may know i inwardly, and read inside it true love-letters; for there I may see openly how much you loved me. Wrong would it be to refuse you my heart, since you have bought heart with heart.

(The Wohunge of Ure Lauerd, pp. 33-5 (with modern punctuation); Anchoritic Spirituality, p. 255

The re-enactment of the Passion events is assimilated by the narrato in a most personal, emotional manner, through brief sentences, affective outbursts and present tense exclamations expressing surprise, shock, and outrage, so as to bring the reader closer to the events themselves. There is both an a-temporal quality and blending of the voices in this passage that allows for complete fusion into the sequence on the part of the meditative reader. Much of the relationship between the I-persona and the person of Christ is based on the language of economic and social difference to express the spiritual inequality and imbalance between them. In this particular setting, Christ takes on the role of the exile, without an abode in the create world, whereas economic wealth and social benefits negatively mark the I-persona in the context of salvation history. Elsewhere, the I-persona mentions kinship as an important aspect of its life before their current devotion to the person of Christ. Class awareness is also pertinent to this theme, with references to men of gentle birth winning too easily women's hearts and depriving them of their virginity:
Ah noble men ant gentile ant of heh burde ofte winnen luue lihtliche cheape, for ofte moni wummon letes hire mensket purh pe luue of wepmon pat is of heh burðe.

But noblemen, gentlemen, men of high birth, frequently win love at little cost, for often many a woman loses her honor through the love of a man of high birth. (The Wohunge of Ure Lauerd, p. 24; Anchoritic Spirituality, p. 250)

In the economy of salvation there is no better gain than to become Christ's beloved. Pe Wohunge of ure Lauerd is ambitious in scope and aspires to bring the reader to an elevated affective level of empathy with, and indebtedness to, the person of Christ. It reflects the penitential concerns of the postLateran world by combining the theme of Christ as lover with a detailed and anxiety-ridden description of the crucifixion which forces a guiltily selfaware re-positioning of the reader-performer as an unworthy sinner.

\section{Thomas of Hale}

These anchoritic works have for long been used as evidence for linguistic continuity between the Old and Middle English periods. However, on the religious front, the apparent specialization of the material for a regional anchoritic audience has until relatively recently pre-empted investigations into the impact of this material upon the larger late medieval religious context. Although there is no space to offer an extensive argument for the influence of anchoritic literature on the language and description of late medieval contemplative experience, one of the first recorded Franciscan lyrics shows how religious themes partake of a large tradition that is shared by different religious orders over different genres and over an extended period of time.

Recent evidence has shown that the Franciscan friar Thomas of Hales had contact with the Queen Eleanor of Provence, wife of Henry III. ${ }^{9}$ Queen Eleanor seems to have had a penchant for Franciscan friars as confessors and spiritual confessors. William Batale, Thomas of Hales, and Adam Marsh were all connected to the queen. Thomas of Hales, who seems to have had a powerful influence upon her, wrote in Latin, French, and English. His Latin life of the Virgin is his most popular work. Another of his extant works is a sermon written in Latin with short prayers written in French. But Thomas of Hales turned to English for the third of his surviving works, the 'Love Rune', composed between I234 and I272. The poem claims that it was written at the instigation of a young maiden, and it is filled with an emotional dimension that would appeal to a girl inexperienced in matters of love and religion. This female character may have decided for a religious life, either as 
a nun or as an anchoress, and the poem shows a mild didacticism in its goal to lead the reader to an exclusive desire for God. The narrator assumes she has already undergone outer conversio (turning away from the physical world) and her apparent request for the 'Love Rune' may characterize her need to be strengthened in her new life devoted to Christ in order to reach inner conversio (psychological transformation to achieve complete absorption in the divine).

Franciscan spirituality broadly belongs to the affective and cataphatic tradition. This tradition works on the emotions of its audience to move their attention from the material to the spiritual world. But even at the higher reaches of the contemplative life the need to respond emotionally is higher reaches of the contenplative life the need to restener to develop considered to be of the utmost importance in leading the listener to develop contemplative feeling. The first stanzas of the 'Love Rune', set as ubi sunt formulae, lamenting the transience of earthly power and beauty, consider formon themes, common thenes, such as the trasichce of me human love. The emotional instability generated by absorption with such issues is pointed out, with a particular focus set on the lovers of the classical and medieval traditions:

\section{Hwer is Paris and Heleyne}

That weren so bryht and feyre on bleo?

Amadas and Ideyne,

Tristram, Yseude, and alle theo?

Ector with his scharpe meyne,

And Cesar riche of wordes feo?

Heo beoth iglyden ut of the reyne

So the schef is of the cleo $(11.65-72) .{ }^{\text {to }}$

beautiful and fair in face

Idoine

those

powerful strengt

wordly wealth

they have vanished; dominion

just as the sheaf is (cut) by the scythe

The reference to legendary heroes of the romance tradition suggests that the recipient may formerly have been a keen reader of such texts herself, and one perhaps familiar with the conventions and practices of secula fin' amor (refined love). But such models and practices no longer fit the he her her will must be turned towards other models and practices, even if such a conversion does not imply a complete negation of her former outlook. The romance heroes are instead used as a springboard to the love of Christ. The technique heroes are instead used as a spers its roots in Bernardine spirituality, in which used by Thoritual sphere, and is transposed to become spiritual itself. The humanity of Christ and the events of his Passion often serve as the intermediary moment for this transference. Most medieval Passion narratives deploy those events with the specific aim of making possible for the audience a transfer from a carnal to a spiritual concern. The $u b i$ sunt formulae serve as a means of denying the physical world and the use of fin' amor vocabulary expresses a form of eternal and abstractly idealized love. In stanzas $12-19$, the charms of Christ, and the invitation to the maiden to become his bride are followed by a description of the glories and bliss of Christ's eternal abode. Stanza eighteen describes the bliss of the sight of Christ and stanza nineteen concludes this moment of the poem with the gift to the maid of the precious treasure, her virginity. The poem tactfully builds a generous portrait of her new spiritual lover, so that from an initial desire to set her will towards God it moves to triggering a strong desire for his sight:

A! Swete, if thu ikneowe

The gode thewes of thisse childe -

He is feyr and bryht on heowe,

Of glede chere, of mode mylde,

Of lufsum lost, of truste treowe,

Freo of heorte, of wisdom wilde -

Ne thurhte the never reowe

$\begin{array}{ll}\text { Ne thurhte the never reowe } & \text { you would never regret it } \\ \text { Myhtestu do the in His ylde! (11. 89-96) } & \text { were you to put yourself; protection }\end{array}$

To concepts of a highly abstract, almost Neo-Platonic-like nature, comparison is made with individuals of this world, and the power of this ethereal practice of love is even measured against that of the king of England himself:

He is ricchest mon of londe,

So wide so mon speketh with muth; $\quad$ as far as men speak with mouth Alle heo beoth to His honde,

all are at his command

Est and west, nct

Henri, King of Engelonde,

Of Hym he halt and to Hym buhth.

Mayde, to the He send His sonde,

knew

qualities

in appearance

centerament

amorous desire

noble; strong of wisdom

And wilneth for to beo the cuth (Il. 97-TO4) desires to be (or messenger)

Henry III (reigned I2I6-72) was a great benefactor of the church, with the building of the new gothic church of Westminster Abbey as the most ostentatious sign of his religious devotion. Thomas of Hales may have written his poem after the queen turned to him for spiritual direction and while or after Westminster Abbey was built in a record time of twenty-four years (I245-69). While the building of Westminster Abbey is not specifically mentioned in the poem, references to Solomon's temple (1l. I I3-20) and other building imagery recall the construction of an English templum dei whose magnificence echoed that of Solomon's temple. 
In the poem, the expression 'bolde' (1. II3) alludes to Solomon's temthe the Heavenly Jerusalem, Christ's body and, more importantly here, the pe, the Heavenly Jexter human body. But 'bolde' refers also to a lady's bower, an image used repeatedly in Ancrene Wisse, and one that becomes the structural metaphor fo the anchoritic text Sawles Warde. Further the use of 'mote' (1. I2I) in the 'Love Rune' refers also to a contemporary castle, perhaps of Norman design (move Ruce at this moment (motte-and-bailey type) and the use of this enclosed space at this moment in the poem, invites a deeper focus on the interior life with a further development of the trope of enclosure which characterizes anchoritic literature. Recognition of the significance of one's own interiority makes possible a Recognition of the suality of the everyday referen

\section{Ne may no mon Hine iseo}

$\mathrm{Al}$ so $\mathrm{He}$ is in His mihte

That may withuten blisse beo;

Hwanne he isihth ure Drihte,

His sihte is al joye and gleo!

He is day wythute nyhte!

Nere he, Mayde, ful freo

That myhte wunye myd such a knyghte? (11. 137-44) $\begin{aligned} & \text { privilege } \\ & \text { dwell with }\end{aligned}$

see Him
entirely as
who
sees
gladness
privilege
dwell with

Such moments of bliss are only possible through the preservation of the maiden's literal and metaphorical virginity. Indeed, towards the end of the maiden's litity a be delivered only poem, virginity becomes its main topic. Spiritual biss will be dhivered only upon condition of the preservation and protection of this most marvellous gem.

This stress on the value and importance of virginity within the 'Love This sulminates in making possible Rune' does not preclude a movene a strong contemplative feeling for the audience, characterized by a desire for the experience of union with the divine. Indeed the force of virginity as metaphor for purity makes possible this desire through a fine-tuning of fin meta spiritual potential omor values which are transformed so as to catalyze. Such an approach is however not without some ambiguities. Indeed, in a few passages of the 'Love Rune', the persona of the narrator is rather ambivalent. First, his answer to the maiden's request for a 'love rune' is not clear. What is the maiden really asking for? A love song, a piece of is not clear. Wriar Thomas wisdom on love, or perhaps a private message between lovers? Friar seems to play with linguistic ambiguity and to transfer that ambiguity to the role which he enacts with the maiden. For lines 185 to 192 refer once again to the request of the maiden for a 'luve rune' and the narrator's words could the maiden had a choice between the narrator himself and Jesus. This is of course a reading which plays with the possibly literal and secular meanings of the amorous language used in the poem and it may be that the poet wishes to exploit such an ambiguity to coerce the reader to calibrate his contemplative feeling when reading the text. The maiden, or any other reader, should turn back to the text, memorize it, and sing it 'mid swete stephne' (1. 203). The 'Love Rune' is not to be read for pleasure but in order to focus correctly one's own will and spiritual direction. It makes an intelligent and strategic use of the affective spirituality whose precursors were, among others, Anselm of Canterbury, Bernard of Clairvaux, Francis of Assisi and the early Franciscans. The 'Luve Rune' and the anchoritic works make strong claims for the preservation of virginity and thus they obviously address, in the first instance, a readership of female virgins. If contemplative claims are therefore intimately linked to the preservation of this privileged female condition, evidence is plentiful for attesting to later male interest in those texts.

\section{John of Howden}

The texts from the Ancrene Wisse group were written in the West Mid land dialect and attest to a very active vernacular literary activity in remote regional settings. However, as has been shown with Thomas of Hales, the devotional demands of the court of Henry III and his queen Eleanor of Provence also played a significant role in triggering the composition of vernacular pieces. The writings of the Northerner John of Howden, chaplain to Queen Eleanor, owe much to the appetite for devotional literature in the queen's court. ${ }^{\text {II }}$ We know very little about John of Howden, (and even less if he is not, as recent scholarship argues, the John of Howden who was prebendary of the church of Howden in Yorkshire). But, the works which are attributed to him, like those of his contemporary Thomas of Hales and the later major Yorkshire author Richard Rolle, display a multilingual flexibility. There is a body of Latin texts, such as his Philomela (Song of Love); Canticum amoris (Song of Love); Cythara (Cittern); Quinquaginta cantica, Quinquaginta salutationes (Fifty Songs; Fifty Salutations), and several other shorter Latin poems. But he also wrote in Anglo-Norman: Li Rossignos (The Nightingale) is a re-working of Howden's own Latin Philomena, with borrowings from the anonymous Desere iam anima (Abandon Now O Soul). ${ }^{\text {I2 }}$ This account of the life of Christ is dedicated to the queen mother Eleanor (c. I223-9I), 'Mere au roi Edward', which means that the dedication, at least, was written after the death of Henry III in $\mathrm{r} 272$ and his son's accession to the throne as Edward I. ${ }^{13}$ Internal evidence also suggests that the poem was written before 1282 . One of the characteristics of this 5,272 -line poem 
is the emphasis placed on the developing devotion to the Name of Jesus, is the erk suggesing that in, and influenced by, Cistercian spirituality. ${ }^{14}$ Section XXX of the poem is entirely devoted to the Name, with a coda on this theme in Section XXXII The enormously popular and influential hymn Dulcis Jesu memoria (Jesus the Memory is Sweet), composed in England by a Cistercian author, inspired the Memorive is Stanzas ten and an extensive meditation on this theme in $L i$ Rosignos.s Stanzas ten an eleven make direct allusion to the sweetness of the name celebrated in the Cistercian hymn:

Douz Noun 'jhesu'! fai que te chante Quant la Mort mordra la plante!

Vien en ma langue et la te plante,

Que li pleidur ne me sosplante!

'Jhesu', douz Noun! Se je te troeve

En ma lange quant Mort m'esproeve,

Ce me serra lors droite proeve

D'avoir la joie toz tenz noeve.

Douz Noun! Pur celi qi te porte,

Vien lors a moi et me conforte,

Kar si de toi lors me desporte,

Tote ma peine serra morte!

En toi, douz Noun, est alejaunce

Et de la mort et de grevaunce,

Vigor qui ja n'avra faillaunce,

Et joie qui n'ad esmaiaunce!

Sweet Name 'Jesus'! Do that I sing it when death bites the plant! Come on my tongue and put yourself in there, so that the pleader does not uproot me! 'Jesus', sweet Name! If I find you on my tongue when Death tests me, it will be then for me direct proof that I will have new joy for ever.

Sweet Name! for the one who carries you. Come to me; comfort me, because if I am then removed from you, all my effort will be lost! In you, sweet Name, is my relief, against death and grievance. It is unfailing strength and joy without dismay ${ }^{16}$

The poetic meditation on the Name digresses from the general intention f the poem which offers a detailed account of the life of Christ. It partakes of the sam a f making of such influential texts of the same affetive tradion which saw the making of su influential texts as the late thirteenth-century Stimulus amoris (Goad of Love) by James of Milan, the Meditationes vitae Christi (Meditations on the Life of Christ), probably written by the Franciscan friar Johannes de Caulibus in the early fourteenth century, and Ludolph of Saxony's (d. 1377) Vita Jesu Christi, also known as the Speculum vitae Christi (Mirror of the Life of Christ). $L i$ Rossignos had a significant impact on later English devotional writers. ${ }^{\mathrm{I}}$ The Middle English Meditations on the Life and Passion of Christ, probably written during the second half of the fourteenth century, was influenced by both Howden's Philomela and his Rossignos, together with passages clearly indebted to some of the writings of Richard Rolle. ${ }^{18}$ The way that this text is adapted from Latin into Anglo-Norman for a royal female audience, only to find its way later into yet another significant transformation into Middle English, well describes the ways in which medieval English contemplative writings are part of a multilingual textual exchange which manifests itself in Latin, Anglo-Norman, and English.

\section{Richard Rolle}

There is no evidence that Richard Rolle (c. I300-49) wrote in AngloNorman. He owes his modern-day fame to his contributions in English, with his three letters (The Commandment, Ego dormio (I Sleep) and The Form of Living) written for the attention of female recipients, his lyrics and his two Passion meditations as his most well-known pieces. ${ }^{19}$ But, like John of Howden, Rolle wrote far more in the Latin language than in the vernacular during the course of his literary career. A brief biographical sketch of Richard Rolle may provide us with a partial explanation for this. ${ }^{\circ}{ }^{\circ}$ Rolle was born at Thornton, near Pickering in Yorkshire. He was the son of William Rolle. Thanks to the financial support of Thomas de Neville, he went to study at Oxford, which he left without a degree at the age of nineteen. Some time after his return to Yorkshire, he led the life of a hermit and found an abode in the estate of John de Dalton, whose son had met Rolle during his Oxford days. After leaving the Dalton estate, Rolle for some time moved from one abode to another, finally finding a more permanent dwelling near the nunnery at Hampole in Yorkshire. There he acted as spiritual guide to at least one of its nuns, Margaret Kirkeby, who had already chosen the anchoritic life when Rolle worked as her spiritual advisor. He died near Hampole in I 349. Although Rolle's own account of devotional and contemplative experience is based on the long-established western tradition which the Cistercian and the Franciscans circulated and popularized in the twelfth and thirteenth centuries, he is today better known for some of the idiosyncrasies of his contemplative programme. For instance, Rolle makes the daring claim of living in a permanent state of union with the deity, of hearing heavenly melody at all times, and of experiencing particular physico-contemplative feelings such as fervor, dulcor, and canor (heat, 
sweetness, song). In some of his autobiographical moments, he also shows . In som the has in his contemplaive system. However, an overall study of Rolle's substantial corpus shows his great linguistic, generic and devotional versatility. The English writings comprise only a quarter of the surviving works, and are much shorter than those composed in Latin. Alongside books of ascetic guidance, handbooks for parish priests, commentaries of the Psalter and other biblical books, his strictly contemplative writings, in Latin or Middle English, are a relatively small part of his output. One must take into consideration this generic and textual versatility in order to offer a credible account of Rolle's career. In contrast to oxplores medieval religious generic variety profusely, with the writing of commentaries, postils, religious autobiographies and visions, pastoral manuals, epistles, rules and lyrics. ${ }^{21}$ His generic versatility, his pastoral concerns and the emotive nature of several of his writings contributed to his popularity in the fourteenth and fifteenth centuries. ${ }^{22}$ Rolle belongs first and foremost to the post-Lateran Latin tradition which stresses the cura animarum (care of souls). Some of his writings, like the Judica Me (Judge Me) and some of his earlier commenaries, cover pastoral purposes. They would have empowered parish priests by giving them the necessary material to ruminate on when searching the soul of their parishioners during the sacrament of confession. Rolle himself seems to have moved from a gradual sense of his own sinfulness in his early pieces, to a greater sense of spiritual identity in his middle works. His late Middle English works show the degree of confidence he has reached in his activity as spiritual guide for nuns and female anchorites. ${ }^{23}$

Many of Rolle's texts are deeply affective in nature, appealing to the emotion of his audience in order to move it to a stronger desire for God. The ways in which Rolle suggests the soul is moved to the love of God have sometimes been considered controversial by scholars. At times Rolle overtly projects himself and his experiences as a superior model of the spiritual life. Also he makes contemplative claims that some of his contemporaries deemed excessively ambitious. The Latin Incendium amoris (The Fire of Love is autobiographical at times and it shares many of the weaknesses and qualities which are hallmarks of his textual output, such as the apparent desire for self-promotion and the construction of an authoritative narratorial presence, but these are also mixed with moments of great sincerity. Of the five 'Middle English mystics', Rolle is pe touching the affection in order to trigger contemplative feeling. For that reason, he belongs to a tradition marked by the impact of pastoral theology and spiritual psychology as spread by the friars.
The Latin Melos amoris (Song of Love) is a postil (an expository discourse inspired by a biblical book) on the Song of Songs. Melos stands a a pivotal text, in which pastoral and more contemplative passages cohabit. The generic form of this piece is occasionally thwarted by the insertion of autobiographical passages which convey Rolle's personal views about the religious life. It is revealing of Rolle's own concept of the religious life, and shows that, together with contemplative aspirations, he was also very much aware of the need for basic instruction. The extract below is made up of patchwork of contemplative and contempt-for-the-world passages which is characteristic of the entire piece:

Spiritus specialis, inspira spiramen: quemadmodum cupio carnem calcare et carere cupidine squalore cooperta, ita et integre animer amore Auctoris et ambulem ad alta ardens amore. Forma feminea non flectet firmatum nec puritas pacifica pectoris pii putredini patebit, sed spreta spurcicia Speciosum in ad oculos Amati. Sanctus secernitur a seculi singultu, et singulare solacium, scilicet celeste, sumit incessanter, corporale contagium continue conquassans. Terror tristicie trahetur a tali et thronus Trinitatis in thalamo tuetur tacite triumphans tormenta tiranni. ${ }^{24}$

O friendly Spirit, send me your inspired breath: I wish to scorn the flesh and deprive myself of this sordidly clothed concupiscence and, vivified by the love of my Author, I want also to walk towards the peaks in the ardor of this love. Woman's beauty will not make me tremble, because I am now strong. In its purity and peace, my heart full of tenderness cannot let corruption invade it. Showing contempt for impurity, it is the God of Beauty which I wish to see in its splendor. I try to in its splcndor. I try to gaze at its deph, boldly setting wy eyes into those of the Beloved. The saint is protected from the weeping world and he enjoys ceaselessly a singular consolation - that is that of heaven - as he wins constant victories over carnal attraction. Fear of unhappiness is banished from such a soul. Protected by the Trinity, of whom she is the throne and nuptial chamber, without noise she triumphs from the persecutions of the Tyrant.

In other passages Melos disengages itself from the carnal-spiritual dichotomy to focus more on the metaphorical potential of the vocabulary of love. It is, however, illuminating to see in a text praised for its autobiographical and contemplative qualities traces which show the influence of pastoral literature. The world, the flesh, and the devil are the enemies against which the sinful soul has to engage its fight in its journey towards union with God. Rolle incorporates and accommodates such pastoral concerns in his most ambitious religious pieces, be they written in Latin or the vernacular. 
This ongoing concern for pastoral material, with which Rolle possibly This ongoing concern for paccount for his succes (n) as a religious author. Even the pieces written towards the end of his career, such as Ego dormio, display a concern for all the stages of the religious life. This piece shows how triggering contemplative feeling can be achieved in This piece shows how to the context of early fourteenth-century religiosity. Ego domio is an episte addressed to a nun and it offers a systematic approach to the contemplative life, based on three degrees of love which correspond to different states of spiritual consciousness and religious engagement. The first degree of love is experienced when one follows the Ten Commandments and avoids commit experien of the seven deadly sins. The second degree of love is achieved when ting one of the seven deadly sins. The second degree of love is ache one forsakes the world completely, including parents and siblings. The third degree of love corresponds to a state that Rolle defines as the contemplative life. He defines this first in rather pragmatic terms as a solitary mode of life, marked by a thought process in which prayers deliquesce into joyful song and thoughts transform into heavenly melody. This epistle is marked by a high degree of performativity. It attempts to lead its reader/listener to an affective feeling which will prompt and encourage spiritual performance. Fach progressive level of consciousness is encapsulated in a lyrical outburst Each progessive lack that crowns and defines the degree of the religious experience. ${ }^{2}$ In each lyric, Rolle addresses and analyses the particular feeling that one is likely to experience when living in one of the three degrees of love. The epistle ends with a lyric corresponding to the third, i.e. highest, degree of love, which defines a pure spiritual form of love directed in this particular case at the person of Jesus. For the third degree, he writes:

In pis degree of loue al drede, al sorrow, al wo, al ydel ioy and al wicked delites is put fro vs, and we lyve in swetnesses of heuyn. Thynk euer to lest, and to be bettyr and better, and pat wil gif pe grace to love hym, as he doth another. (Ogilvie-Thomson, Richard Rolle, p. 32)

The lyric, which Rolle calls 'a songe of love', is to be performed when The Latin one is being ocu the epistle, Ego dormio et cor meum vigilat (I sleep verse which begins the epistle, Ego dormio et cor meum vigilat (I sleep and my heart is vigilant) (Song of Songs $5: 2$ ), is only one of the instances of borrowing and influence of the Song of Songs for the making of this piece. The kind of feeling that Rolle tries to trigger with his request for the piece. The kin the Song of Songs is contemplative. But of course the lyric itself does not provide the feeling without a genuinely participatory performance. This is possible only if the performer apprehend it with a pure intention. One has to love Jesus Christ in order to experience contemplative feeling:
Ihesu my savyour, Ihesu my confortour, of fairnesse be floure, My helpe and my sokour, when may I se pi toure? When wil pou me kale? Me langeth in to pi halle

To se be and byn alle. Thi love let hit nat falle.

The strikingly strong sensuality of the piece is inspired by the Song of Songs and fin' amor vocabulary. Further, the narrative voice calls for Jesus' mercy so that union be made possible now:

$$
\begin{aligned}
& \text { When wil pou rewe on me, Ihesu, pat I myght with pe be, } \\
& \text { To loue and loke on pe? My sete ordain for me, } \\
& \text { And set pou me perin, for pan may we never twyn, } \\
& \text { And I pi loue shal synge progh syght in py shyninge } \\
& \text { In heuyn withouten endynge. Amen ... }
\end{aligned}
$$

Rolle's strategies cannot be properly understood without appreciating his stress on the necessity of a proper performance of the song of love. Some scholars have argued that the sexual double-entendres between lovers, largely derived from the Song of Songs, contribute to the making of the Rollepersona as messenger between lovers, guiding the female recipient to direct her love message through him to Jesus. In this case, Rolle's epistle would have the same kind of linguistic ambivalence as Thomas of Hales's 'Love Rune'. But although the early part of the epistle functions in a dialogic fashion, with the narrator fashioning himself as an expert in love and spiritual guidance, and asking the female recipient to surrender to his advice, the later, more lyrical parts of the epistle work to delete this dialogic exchange, effacing the narrator and giving the lover the initiative for a direct dialogue with Christ. The lyrics are for the recipient to be performed on uniquely direct personal terms. Rolle does not write down the experience of contemplative feeling, he only offers a textual rendering which may or may not trigger it in the performer.

These texts are only a small fraction of the enormous output of religious texts written during the period I2I 5 to I349. Ancrene Wisse, Thomas of Hales's 'Love Rune', are written by friars (probably a Dominican friar in the case of the Ancrene Wisse, definitely a Franciscan friar in the case of the 'Love Rune'). With Rolle's Ego dormio, they are all influenced by the affective mystical tradition that the Cistercians spread in the twelfth century, and which the friars developed for lay use in the thirteenth century as part of their pastoral mission following the Fourth Lateran Council. Another characteristic shared by these texts is their high degree of performativity. The 'Love Rune' is clearly a text to be performed, as is indicated in the last stanza: 'Hwenne thu sittest in longynge,/ Drauh the forth this ilke wryt:/ Mid swete stephne thu hit singe,/ And do al so hit the byt. (11. 20I-4). The 
lyrics which make an integral part of Ego dormio are also to be performed, as in Rolle's other English epistles which use similar lyrics. Contemplative experience cannot be confined to a textual setting: the latter necessarily points to its own performative qualities. Performativity may be part of the answer in our aim at qualifying contemplative texts and the kind of feeling they hope to generate on the part on their performers in their requiremen for active engagement. Many of the vernacular devotional and mystical texts written during that period initially address a female readership: three anchoresses in the case of Ancrene Wisse for instance, a young maiden just having become a nun in the case of the 'Love Rune', Queen Eleanor in th case of Li Rossignos, and a nun in the case of the Ego Dormio. But it would be too simplistic to conclude that affective religious literature was considered to appeal mainly or only to a female public. Some of Rolle's writings, written in the Latin language for a male clerical audience, show the same kind of affective tone as the pieces addressing female audiences. And after his death his vernacular works proved to have a hugely successful impact and spread beyond the nunnery and the anchorhold to an increasingly wider readership with the appetite for vernacular spiritual writings among literate lay men and women.

\section{NOTES}

I For a translation of Canon ro, see the version offered in Siegfried Wenzel, Latin Sermon Collections from Later Medieval England: Orthodox Preaching in the Age of Wyclif (Cambridge: Cambridge University Press, 2005), p. 229.

Leonard Boyle, 'The Oculus sacerdotis and Some Other Works of William of Dealo' TRHS 'Th Or. (I955), 8I-110; repr. in Boyle, Pastoral Care, Clerical Education and Canon Law, I $200-1400$, Pp. 8 I-I IO.

'Cducation and Canon La, 'co-mplatio', translates the Greek word theoria 'Conter which the root to means to see, defines a limited, elitist form of interior life.

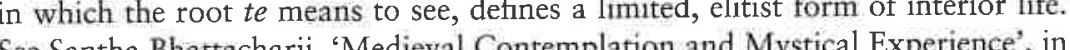
See Santha Bhattacherience, in Dee Dyas, Valerie Edden, and Roger Elis (eds.), Approaching Medieun English Anchoritic and Mystical Texts (Woodbidge. D. S. esp. p. 5 I.

4 See Robert Hasenfratz (ed.), Ancrene Wisse, TEAMS (Kalamazoo, MI: Western Michigan University, 2000), p. 67.

5 Ancrene Wisse, p. 371. Anne Savage and Nicholas Watson (eds.), Anchoritic Spirituality: Ancrene Wisse and Associated Works (New York: Paulist Press, 1991), p. I 87

6 Bella Millett and Jocelyn Wogan-Browne (eds.), Medieval English Prose for Women: From the Katherine Group and Ancrene Wisse (Oxford: Oxford University Press, 1992), pp. 56-7.

7 For a study of medieval virginity in the Katherine group, see Sarah Salih, Versions of Virginity in Late Medieval England (Woodbridge: D. S. Brewer, 200I), esp. pp. 4I-IO6.
8 The Wooing Group consists of the following texts: pe Wobunge of ure Lauerd, On God Ureisun of God Almihti, On Lofsong of Ure Louerde, and On Lofson of Ure Lefdi. For an edition, see W. Meredith Thompson (ed.), The Wohunge of Ure Lanerd, EETS OS 24I (1958). See Salvina Westra (ed.), A Talkyng of pe Loue of God, Edited from MS. Vernon (Bodleian 3938) and Collated with MS. Simeon (Brit. Mus. Add. 22283) (The Hague: Martinus Nijhof, x950).

9 See Margaret Howell, Eleanor of Provence: Queenship in Thirteenth-Century England (Oxford: Blackwell, x998), pp. 92-4.

to References by line number are to the following edition: Susanne Greer Fein (ed.) Moral Love Songs and Lament (Kalamazoo, MI: Medieval Institute Publicatio, 1998). I have used here the electronic version available at: www. lib.rochester ed camelot/teams/lovefrm. htm. See also Betty Hill, "The "Luve Ron" and Ther.ed Hales', Modern Language Review 59 (1964), and 'The History of Jesus College, Oxford MS. 29', Medium Ævum 32 (1964), 203-I3. See Malcolm Robert Moyes (ed), Richard Rolle's Expos

I See Malcolm Robert Moyes (ed.), Richard Rolle's Expositio super Novem Leciones Mortuorum, vol. I, (Salzburg: Institut für Anglistik und Amerikanistik, 988), pp. 47-53. For a reconsideration of the identity of John of Howden, the author, with John of Melton, prebendary of the church of Howden, see Glynn Hesketh (ed.), Rossignos by John of Howden (a thirteenth-century meditation on the passion of Christ), ANTS (2006). I am grateful to Glynn Hesketh for having shared with me information about the author of Rossignos. For further evidence of the role played by Howden at the royal court, and especially for Queen Eleanor, see Margaret Howell, Eleanor of Provence, pp. 83, 97-8.

I2 The reference to Li Rossignos is found in Cambridge, Corpus Christi College, MS $47 \mathrm{I}$, fol. IIIr. For a description of the manuscript, see Nigel Wilkins, Catalogue des manuscrits français de la bibliothèque Parker (Parker Library) Corpus Christi College Cambridge (Cambridge: Parker Library, x993).

I3 Edward I's coronation ceremony took place on I9 August I274, seventeen days after Edward's arrival in England on 2 August I274. See Howell, Eleanor of Provence, pp. 287-9I.

I4 The poem makes direct reference to images and characters borrowed from the romance world. It also allows for significant meditative digressions on several devotional topics. For the influence of the hymn Dulcis Iesu Memoria on the devotion to the Name of Jesus, see Denis Renevey, 'Anglo-Norman and Middle English Translations and Adaptations of the Hymn Dulcis Iesu Memoria' R. Ellis and R. Tixier (eds.), The Medieval Translator/Traduire au Moyen Âge, vol. 5 (Turnhout: Brepols, I996), pp. 264-83.

I5 See Moyes, Richard Rolle's Expositio, pp. 34-7. Stanzas 342 to 372 of Philomela have the devotion to the Name of Jesus as their main theme. (Information provided by Glynn Hesketh in private communication.)

I6 Andrew Lawson King, 'A Critical Edition of Li Rossignos' (unsubmitted PhD thesis, University of Cambridge, I984), p. 275. Translations are my own.

I7 For a brief account of Ludolph of Saxony's Vita Jesu Christi, see Alber E. Hartung (ed.), A Manual of the Writings in Middle English 1050-1 500 (New Haven, CN: The Connecticut Academy of Arts and Sciences, 1993), pp. 3108-9. See also Elizabeth Salter, 'Ludolphus of Saxony and his English Translators', Medium Ævum 33 (1964), 26-35. For an account of the influence of Howden on Rolle, see Moyes, Richard Rolle's Expositio, pp. 47-53. 
I 8 The Meditations on the Life and Passion of Christ is preserved in only one manuscript, London, British Library, MS Additional II 307 . For an edition o this text, see Charlotte D'Evelyn (ed.), Meditations on the Life and Passion of Christ. From British Museum Addit. MS. II 307 , EETS OS 158 (I92I).

See S. J. Ogilvie-Thomson (ed.), Richard Rolle, Prose and Verse, EETS OS 29

9 See S. Ond Ollected Prose and Verse with (1988) and Ratph Terts, FETS OS 329 (2007). For a modern English edition of Rolle's English writings, see Rosamund S. Allen (ed.), Richard Rolle: The English Writings, The Classics of Western Spirituality (New York: Paulist Press, I989). Writings, The Classics of Western Spire written in I 380 in hope of Rolle's can-

20 The Officium et Miracula, which were witen in onization, provides most of the basic intor. However, one needs to be careful no reason to doubt that kind of information. How iner, one needs to be carefl about much else, as the documents were drawn in order to strengthen Rolle's case for canonization. The information above is borrowed freely from Nicholas Watson's own rendering of this document. See Nicholas Watson, Richard Rolle and the Invention of Authority (Cambridge: Cambridge University Press, I991), pp. $31-53$.

2I For a consideration of generic variety in Rolle's corpus, see Denis Renevey, 'Richard Rolle', in Dyas et al., Medieval English. Texts (Woodbridge: D. S. Brewer, 2005), pp. 63-74. For a consideration of the way in which the commentary tradition of the Song of Songs shaped Rolle's mysticism, see Denis Renevey, Language, Self and Love: Hermeneutics in the Writings of Richard Rolle and the Commentaries on the Song of Songs (Cardiff: University of Wales Press, 2001).

22 For an example of accommodation of Rolle's writings, see E. A. Jones (ed.), The 'Exhortacion' from Disce Mori, Middle English Texts 36 (Heidelberg: Universität Verlag Winter, 2006); see also by Jones, 'A Chapter from Richard Rolle in Two Fifteenth-Century Compilations', Leeds Studies in English n.s. 27 (1996), 13962

23. For a chronology of Rolle's writings and the works belonging to the early, middle and late categories, see Watson, Richard Rolle, pp. 273-94

For a brief discussion of Melos, see Renevey, Language, Self and Love, pp. 9124 For a brief discussons (Melos r02. François Vandenbroucke (ed.), Rich (Paris: Cerf, I97I), p. 226. The English Amoriss, vol. I, Sources Chreting translation, based on the Latin text and the French fais translation, is my own.

25 For further discussion on Rolle and performance, see Denis Renevey, Mystical

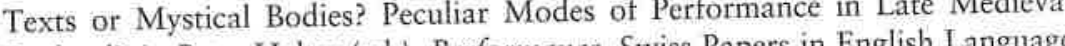
England', in Peter Halter (ed.), Performance, Swiss Papers in English Language
and Literature II (Tübingen: Gunter Narr, I998), pp. 89-104.

\section{JEREMY CATTO}

I349-I4I2: culture and history

The death of Richard Rolle, probably on 29 September I349, marks the beginning of a new period in the practice of the contemplative life in England. A recluse latterly resident at Hampole in the south of Yorkshire, he would be noted in the district for his miracles and would be the focus of a local cult, playing a traditional and respected part not greatly changed, perhaps, since the seventh century. On the other hand, he was among the first European contemplatives to combine the description of his religious experiences, previously a literary genre characteristic of female enthusiasts like Mechtild of Magdeburg, with a grasp of mystical theology which enabled him to direct the spiritual life of nuns and recluses. His English successors Walter Hilton and the author of the Cloud of Unknowing would direct their readers in the contemplative art with the authority of personal experience, correcting in the process the undisciplined religious emotion which they associated with Rolle. He was the pioneer of an art which would cease to be the exclusive practice of monks and recluses and would by stages enter the mainstream of lay religious practice, a process far from complete by I $4 \mathrm{I} 2$.

Rolle's works of instruction, notably the Incendium amoris (Fire of Love), the Emendatio vitae (The Amending of Life) and the Form of Living, were written largely though not exclusively for nuns and hermits; they were composed both in Latin and English, and it is likely that at first they were know only to a small circle of Yorkshire admirers: Margaret Kirkeby, for whom more than one of them were written, the nuns of Hampole, and other recluses of the vicinity (a hermit of Tanfield owned a Rolle text in I409), together with their lay patrons of the Scrope and FitzHugh families. ${ }^{\mathrm{I}}$ After $\mathrm{I} 390$ the seem to have become known in the circle of Thomas Arundel, archbishop of York ( $1388-96)$ and to have enjoyed wide popularity in the fifteenth century, being copied and translated systematically for an increasingly lay readership both in England and abroad. Their fate illustrates a dominant theme in the 